\title{
Efficient immunoselection of cytolytic effectors with a magnetic cell sorter
}

N. Jacobs, M.P. Moutschen, J. Boniver, R. Greimers and N. Schaaf-Lafontaine

Department of Pathology, University of Liège, 4000 Liège (Belgium)

Summary: This paper describes a rapid and efficient method for the sorting of in vitro activated cytolytic effectors cells. For cytotoxic assays, a large number of cells with conserved function must be rapidly obtained. Immunomagnetic sorting was chosen because it is faster than flow cytometry sorting. The MACS system requires the use of paramagnetic beads of small diameter $(100-150 \mathrm{~nm})$, reputed to interfere minimally with cell function. In order to generate the cytolytic effectors, peripheral blood lymphocytes were cultivated in the presence of interleukin-2 $(50 \mathrm{U} / \mathrm{ml})$ and anti-CD3 monoclonal antibody (BMA030, $100 \mathrm{ng} / \mathrm{ml})$ for 4 days. Cell separation was based on the membrane expression of the CD3 complex. The purity obtained for positive $\left(\mathrm{CD} 3^{+}\right)$ cell sorting with the MACS was higher than $95 \%$. The purity of negative (CD3) cell fraction was more variable, but further purification by flow cytometry rapidly yielded purity higher than $95 \%$. Cytotoxic assays were performed against four target cell lines (K562, Daudi, HL60 and U937) and proliferation assays showed that both negatively and positively selected populations had conserved their function acquired during culture in the presence of anti-CD3 $\mathrm{mAb}$ and IL2.

Keywords: Lymphocyte, Magnetic cell sorter, CD3, Cytotoxicity; Assay, Effector cells, Purity, Rapidity.

\section{Immunosélection de cellules effectrices cytolytiques triées par champ magnétique (MACS)}

Résumé: Cet article décrit une méthode de tri cellulaire rapide et efficace permettant de séparer des cellules effectrices cytotoxiques activées in vitro. Nous avons choisi le tri par champ magnétique car les tests de cytotoxicité à médiation cellulaire requièrent un grand nombre de cellules ayant conservé leurs fonctions. De plus, le système MACS utilise des billes paramagnétiques de petite taille (100-150 nm de diamètre) afin de n'interférer que faiblement avec les fonctions cellulaires. Les effecteurs cytolytiques sont obtenus à partir de lymphocytes du sang périphérique cultivés en présence d'un anticorps monoclonal anti-CD3 (100 ng/ml) et d'interleukine-2 $(50 \mathrm{U} / \mathrm{ml})$ durant 4 jours. La séparation des cellules est basée sur l'expression membranaire du complexe CD3. La pureté obtenue pour les cellules positives $\left(\mathrm{CD}^{+}\right)$triées est égale ou supérieure à $95 \%$. Par contre, la pureté de la fraction cellulaire négative $\left(\mathrm{CD}^{-}\right)$est plus variable, mais une séparation consécutive de cette population par cytométrie en flux permet d'atteindre rapidement une pureté supérieure à $95 \%$. Les tests cytotoxiques réalisés contre 4 lignées de cellules tumorales (K562, Daudi, HL60 et U937) ainsi que les tests de prolifération montrent que les populations sélectionnées négativement et positivement ont conservé leur fonction.

Mots-clés: Lymphocyte, Cytométrie magnétique, CD3, Cytotoxicité; Epreuve, Cellules effectrices.

\begin{tabular}{|c|c|c|c|}
\hline BSA & $=$ bovine serum albumin. & $\mathrm{mAb}$ & $=$ monoclonal antibody. \\
\hline CPM & $=$ counts per minute. & NK & $=$ natural killer. \\
\hline FACS & $=$ fluorescence-activated cell sorter. & PBL & $=$ peripheral blood lymphocyte. \\
\hline FCS & $=$ foetal calf serum & PBS & $=$ phosphate-buffered saline. \\
\hline FITC & $=$ fluorescein isothiocyanate. & $\mathrm{PE}$ & $=$ phycoerythrin. \\
\hline IL2 & $=$ interleukin -2 & РHA & $=$ phytohaemagglutinin. \\
\hline LAK & $=$ lymphokine-activated killer. & rIL2 & $=$ recombinant IL2 . \\
\hline
\end{tabular}




\section{INTRODUCTION}

In vitro stimulation of human peripheral blood lymphocytes (PBL) by antibodies directed against the TcR-CD3 complex and by interleukin-2 (IL2) generates non-specific cytotoxic activity against various tumour cell lines (Ochoa et al., 1987 ; Nishimura et al., 1992). The nature of these cytolytic effectors is likely to be heterogeneous since, in addition to $\mathrm{T}$ lymphocytes, bystander cells can be activated by cytokines released by stimulated $\mathrm{T}$ cells. Given the potential differences in killing and target cell recognition mechanisms, there would be considerable interest in evaluating the activity of each cell subset individually.

Such an approach implies the use of efficient cell selection techniques which fulfill the following requirements : (1) the purity in positive and negative fractions should be high enough (i.e. $>95 \%$ ) to enable accurate analysis of selected cell subsets in the absence of any significant contamination; (2) the technique of selection should not interfere with cell function (the duration of the selection procedures is a critical aspect of this problem) and (3) the yield of sorting techniques should be optimal to ensure recovery of large numbers of cells (i.e. $>0.5 \times 10^{6}$ cells) in a limited period of time. These aspects are crucial for the realization of functional experiments such as 4-h chromium release assays.

The flow cell sorting techniques ensure very high purity (95-99\%). However, the sort is based on cell-by-cell processing and is consequently a long time process which currently lasts several hours (Lindmo et al., 1990). On the contrary, the duration of immunomagnetic selection does not depend on the total number of cells to sort. This is a major concern when several million purified cells are needed for functional assays. Among the immunoselection techniques commercially available (Lea et al., 1985; Gee et al., 1991; Naume et al., 1991), the MACS system (Miltenyi et al., 1990) was chosen because the small size of the magnetic beads (100-150 nm diameter) apparently does not significantly interfere with cell function even in the positively sorted fraction (Pflueger et al., 1990).

This study was designed to determine whether immunoselection with MACS is a practical tool for dissection of the respective participation of cytolytic subsets, particularly $\mathrm{CD}^{+} \mathrm{T}$ cells and non $\mathrm{T}$ cells, in lymphocyte populations activated in vitro. MACS selection established that both T lymphocytes and NK cells are involved in cytolytic activity generated by stimulation with an anti-CD3 monoclonal antibody (mAb) and interleukin-2 (IL2).

\section{MATERIALS AND METHODS}

\section{Antibodies}

Biotinylated $\mathrm{mAb}$ directed against human $\mathrm{CD} 3$ were purchased from Immunotech (Marseille, France). Streptavidin-FITC was obtained from Boehringer Mannheim (Brussels, Belgium). The antibodies used for immunofluorescence assays are listed in table I.

\section{Preparation and culture of PBL}

Fresh heparinized blood from healthy donors (Centre de transfusion de Liège) was diluted 1:2 with RPMI-1640 (Gibco BRL, Gent, Belgium), layered over "Lymphoprep" (Nycomed; Oslo, Norway) and spun at $400 \mathrm{~g}$ for 30 min. The mononuclear cells at the interface were harvested, washed three times and counted. Culture medium consisted of RPMI-1640 supplemented with $1 \%$ non-essential amino acids (Gibco), sodium pyruvate (1 mM Gibco), $30 \mathrm{U} / \mathrm{ml}$ penicillin-streptomycin (Gibco) (completed medium) and $5 \%$ pooled heat-inactivated human AB serum. Cells were cultivated $\left(1.25 \times 10^{6}\right.$ cells $\left./ \mathrm{ml}\right)$ in $25-\mathrm{cm}^{2}$ tissue culture flasks (Falcon, Becton Dickinson) in the presence of $100 \mathrm{ng} / \mathrm{ml}$ of anti-CD3 mAb (BMA030, IgG2a, Behringwerke, Marburg, Germany) and 50 $\mathrm{U} / \mathrm{ml}$ of human rIL2 kindly provided by Glaxo Institute for Molecular Biology (AG, Genève, Switzerland). Cultures were incubated at $37^{\circ} \mathrm{C}$ in a humidified atmosphere of $5 \% \mathrm{CO}_{2}$ for 4 days.

\section{Cell lines}

K562 is an MHC-negative erythroleukaemic cell line commonly used to study NK activity (Lozzio and Lozzio, 1975). The U937 cell line is derived from a histiocytic lymphoma (Sundström and Nilsson, 1976) and is NKsensitive. The Daudi cell line derives from a Burkitt lymphoma (Klein et al., 1968). HL60 is a promyelocytic leukaemia cell line (Collins et al., 1977). Both Daudi and HL60 cell lines are NK-resistant. The four cell lines 
were cultivated in RPMI-1640 supplemented with $10 \%$ foetal calf serum (FCS) (Gibco).

\section{Magnetic cell separation}

A three-step procedure for labelling cells with biotinylated superparamagnetic beads (polysaccharidestabilized/iron complexes, size 100-150 nm, Bee-ton Dickinson) was used. First, the cells were stained in PBS (Gibco) with biotinylated anti-CD3 mAb, anti-Leu-4 (Becton Dickinson) for fresh PBL and IOT3 (Dako) for activated cells at a concentration of $10 \mu \mathrm{g} / 10^{6}$ cells for $20 \mathrm{~min}$. The cells were washed in PBS/EDTA $(5 \mathrm{mM}$, Merck, Darmstadt, Germany) and incubated with streptavidin-FITC at a concentration of $10 \mu \mathrm{g} / 10^{6}$ cells for 20 min. After a washing step, the cells suspended in PBS/EDTA were incubated in the presence of $100 \mu 1$ of 1:100 diluted biotinylated magnetic beads for $5 \mathrm{~min}$. The cells were washed in PBS/EDTA supplemented with $1 \%$ bovine serum albumin (PBS/BSA, Boehringer) and 20-80 $\times 10^{6}$ cells were suspended in a volume of $0.5-1 \mathrm{ml}$ of PBS/BSA. All procedures were performed on ice. The MACS instrument (Becton Dickinson) is constituted principally by a permanent magnet of 0.6 Tesla in which is inserted a column filled with steel wool (Miltenyi et al., 1990). The cell suspension was applied to a precooled $\left(4^{\circ} \mathrm{C}\right)$ separation column saturated in PBS/BSA, and placed in the magnetic field of the permanent magnet. Unlabelled cells were not retained in the column and were collected in a total volume of 3-8 $\mathrm{ml}$ of PBS/BSA. After washing of the column with 3-8 $\mathrm{ml}$ of PBS/BSA, the positively stained cells were eluted from the separation column outside the magnetic field with 5-15 ml in the syringe under gentle pressure. The cells were numerated and the viability was estimated by trypan blue exclusion or propidium iodide staining (Horan and Kappler, 1977). The purity of the positive and negative cell fractions was checked by flow cytometry (FACScan, Becton Dickinson). When needed, further purification was performed by flow cytometry (FACS IV, Becton Dickinson). The conditions of FACS cell sorting to achieve 95$99 \%$ purity were as follows: rate $=1500$ cells $/ \mathrm{s}$, deflected drops $=3$, nozzle tip $=70 \mu \mathrm{m}$ drop generation frequency $=29500 \mathrm{~Hz}$, drop delay $=13$.

The recovery of the sort for each subset was calculated according to the following formula:

$$
\text { recovery }(\%)=\frac{f s \times \mathrm{Ns}}{f t \times \mathrm{Nt}} \times 100
$$

where $f_{s}$ is the frequency of the considered cell subset in the sorted fraction, Ns the total number of cells obtained after sorting, $f t$ the frequency of this subset in the starting, unsorted population and $\mathrm{Nt}$ the total number of cells in the starting population.

Table I: mAb used in immunofluorescence experiments.

\begin{tabular}{llll} 
CD designation & Fluorochrome conjugate & mAb & Company \\
& & \\
\hline CD3 & FITC & IOT3 & Dako \\
CD2 & FITC & T11 & Dako \\
CD4 & FITC(PE) & IOT4(CD4) & Immunotech (Dako) \\
CD & PE & IOT8 & Immunotech \\
CD16 & PE & Leu-11c & Becton-Dickinson \\
CD56 & PE & Leu-19 & Becton-Dickinson \\
CD57 & FITC & Leu-7 & Becton-Dickinson \\
CD20 & PE & Leu-16 & Becton-Dickinson \\
CD19 & PE & IOB4 & Immunotech \\
CD14/CD45 & PE/FITC & Leucogate & Becton-Dickinson \\
CD25 & PE & CD25 & Dako \\
TcR $\alpha \beta$ & FITC & WT31 & Becton-Dickinson \\
TcR $\gamma \delta$ & FITC & TCR $\gamma \delta$ & Becton-Dickinson \\
\hline
\end{tabular}

The mAb were purchased from Dako (Glostrup, Denmark), Immunotech and Becton-Dickinson (Erembodegem, Belgium). 


\section{Immunofluorescence and flow cytometry}

After separation, about $0.5 \times 10^{6}$ unseparated and selected cells were incubated on ice in a volume of $25 \mu 1$ with antibodies defined in table I. After washing, cells were analysed for fluorescence intensity on a "FACScan" (Becton Dickinson). Double-staining was performed on unseparated and negatively selected cells.

\section{Cytotoxicity assays}

Effector cell populations were washed once in RPMI-1640 medium, counted and then suspended in RPMI-1640completed medium $(10 \% \mathrm{FCS})$ at a concentration of $2 \times 10^{4}$ cells $/ 100 \mu 1$. Six serial dilutions were made in 96well U-bottom plates (Nunc). Target cells were incubated with $\mathrm{Na}^{51} \mathrm{CrO}_{4}$ (Medgenix, Fleurus, Belgium) for $1 \mathrm{~h}$ at $37^{\circ} \mathrm{C}\left(100 \mu \mathrm{Ci}\right.$ for $1 \times 10^{6}$ cells in $\left.155 \mu \mathrm{l}\right)$, washed three times, counted and adjusted to obtain 5,000 cells/100 $\mu 1$. This suspension was added to the $100-\mu 1$ serial dilutions of effectors cells. After centrifugation, the trays were incubated for $4 \mathrm{~h}$ at $37^{\circ} \mathrm{C} ; 100 \mu \mathrm{l}$ of supernatant were then recovered from each well and radioactivity was measured in a $\gamma$-counter (Cobra auto-gamma Packard, Downers Grove, IL). Maximal chromium release was obtained by adding $100 \mu \mathrm{l}$ of detergent (RBS $10 \%$ Chemical products) to $100 \mu 1$ of target cells suspension and spontaneous release was given by incubation of target cells without effectors cells. Percent cytotoxicity was calculated according to the following formula:

\section{experimental mean CPM - spontaneous mean CPM \\ maximal mean CPM - spontaneous mean CPM}

\section{Proliferation assays}

Unsorted and sorted cells were plated in triplicate in 96-well U-bottomed plates at $10^{4}$ cells per well in $200 \mu 1$ of medium alone, in the presence of IL2 (50 U/ml) or PHA (1\%) (Difco, Detroit, Michigan). After $24 \mathrm{~h}, 0.4 \mu \mathrm{Ci}$ of ${ }^{3} \mathrm{H}$-thymidine (Dupont NEN, Dreieich, Germany) was added in $25 \mu 1$ of RPMI-1640. Cells were harvested with a cell harvester (Skatron, Lier, Norway) on glass fiber filters after $4 \mathrm{~h}$ and ${ }^{3} \mathrm{H}$-thymidine incorporation was determined by scintillation counting (1500 Tri Carb Packard).

\section{Statistical analysis}

The data were analysed using the Student's $t$ test (StatWork, Cricket software).

\section{RESULTS}

\section{Selection with MACS enables optimal recovery of cells with conserved viability}

Preliminary assays were performed with fresh unstimulated PBL in order to assess recovery and viability after MACS selection. Mean recovery of $\mathrm{CD}^{+}$cells reached $79.5 \% \pm 4 \%(\mathrm{n}=7)$ in positive cell fractions ; the percentage of $\mathrm{CD}^{+}$cells lost in the negative cell fraction and in the wash was always less than $5 \%$ (fig. 1).

The recovery calculated for PBL activated with anti-CD3 mAb (BMA030, $100 \mathrm{ng} / \mathrm{ml})$ and $\mathrm{rIL} 2(50 \mathrm{U} / \mathrm{ml}) \mathrm{was}$ $66 \% \pm 15 \%$ for $\mathrm{CD} 3+$ cells and $64 \% \pm 20.5 \%$ for $\mathrm{CD}^{-}$cells $(\mathrm{n}=4)$ (table II).

Trypan blue and propidium iodide exclusion assays did not reveal any significant increase in cell death after magnetic selection (data not shown).

\section{MACS sorting enables purification of $\mathrm{CD3}^{+} \mathrm{T}$ cells without significant contamination and dramatically enriches NK cells in the negative fraction}

After culture in the presence of anti-CD3 mAb and rIL2, $84 \% \pm 5 \%(n=12)$ of the lymphocytes expressed the $\mathrm{CD} 3$ complex (fig. 2A). After magnetic selection, the purity of $\mathrm{CD}^{+}$and $\mathrm{CD}^{-}$fractions was assessed by flow cytometry. No additional staining step was required, since streptavidin-FITC had been used to bind the biotinylated magnetic beads to the biotinylated anti-CD3 mAb prior to separation. Purity of the positively sorted cell population was always greater than $95 \%(97 \% \pm 1.5 \% ; \mathrm{n}=12)($ fig. $2 \mathrm{~B} 1)$. Purity of the $\mathrm{CD}^{-}$cell fraction was often satisfactory (fig. 2B2), but displayed a higher variability between experiments, ranging from 50 to 
98\%. Consequently, further purification of the CD3- fraction by FACS was realized immediately after magnetic selection if $95 \%$ purity was not obtained. Combined MACS + FACS purification of the CD3- fraction led to optimal purity, with a cell yield superior to FACS selection alone (data not shown).

Fig. 1: Recovery of $\mathrm{CD}^{+}$cells after selection by MACS. Percentages of $\mathrm{CD} 3^{+}$cells are given for the different fractions of the sort. Values represent means $\pm S D$ of 7 experiments.

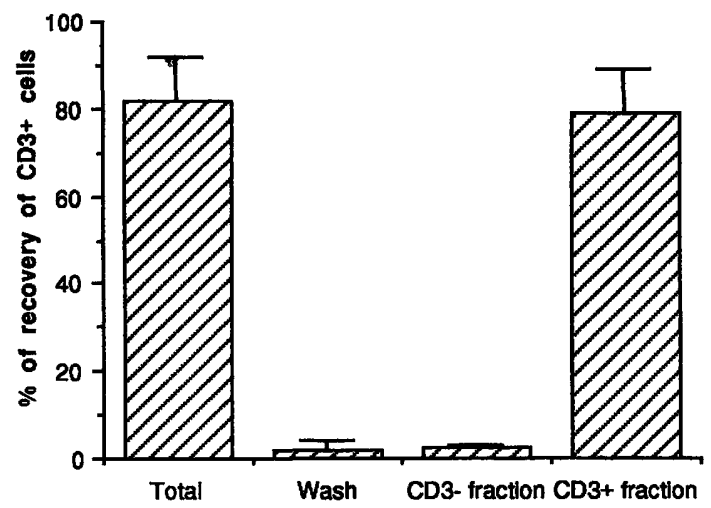

Table II: Recovery of activated cells after sorting.

\begin{tabular}{|c|c|}
\hline $\begin{array}{l}\% \text { of recovery } \mathrm{CD3}^{-} \text {cells in } \\
\text { negative fraction }\end{array}$ & $\begin{array}{c}\% \text { of recovery of } \mathrm{CD3}^{+} \text {cells in } \\
\text { positive fraction }\end{array}$ \\
\hline
\end{tabular}

\begin{tabular}{lcc}
\hline 1st separation & 80 & 46 \\
2nd separation & 60 & 65 \\
3rd separation & 36 & 72 \\
4th separation & 79 & 82 \\
Mean \pm SD & $64 \pm 20.5$ & $66 \pm 15$ \\
\hline
\end{tabular}

To further confirm the purity of MACS sorting by an additional staining step independent of magnetic selection, a panel of mAb was used to determine cell surface phenotype in unseparated and purified $\mathrm{CD}^{-}$and $\mathrm{CD}^{+}$cell fractions. Most cells cultivated in the presence of rIL2 + anti-CD3 mAb and unsorted (table III) were T lymphocytes bearing the TcR $\alpha / \beta$, whereas a minority of cells expressed the TcR $\gamma / \delta$. The CD $4 / C D 8$ ratio after 4 days of culture was unchanged compared to fresh PBL. Few cells $(<6 \%)$ expressed NK markers (CD16, CD56, CD57). In the $\mathrm{CD}^{-}$cell fraction obtained by combined MACS + FACS purification (table III), the majority of the cells in this fraction expressed at least one NK cell marker. Dual-color analysis revealed that a significant proportion of the cells bearing NK markers were weakly positive for CD8 (CD8 ${ }^{\mathrm{dim}}$ ). It is noteworthy that lymphocytes with a high expression of CD8 $\left(\mathrm{CD} 8^{\text {hi }}\right)$ could not be found in the negative fraction, and contamination by $\mathrm{CD}^{+}$cells was always less than $5 \%$. B lymphocytes identified by CD19 represented $27 \%$ of the cells in the $\mathrm{CD}^{-}$fraction. In the $\mathrm{CD}^{+}$fraction (table III), T cells expressed either CD4 or CD8 on their surface. Few or no cells displayed the CD16, CD56 or CD20 molecules.

Expression of the low affinity IL2 receptor (CD25) was studied in order to estimate the activation of the lymphocytes. In the unsorted population, CD25 was found on a large proportion of lymphocytes $(67 \%)$ (table III). In the $\mathrm{CD}^{+}$cell fraction, a similar number of cells with low affinity receptors for IL2 (71 \%) were observed. On the other hand, only $38 \%$ of the lymphocytes in the $\mathrm{CD}^{-}$fraction were found to be positive for CD25. 
Fig. 2: FACS analysis of CD3 expression before and after $M A C S$ purification of $C D 3^{+}$and $C D 3^{-}$fractions. Fluorescence 1 (FITC) histograms are shown for one representative experiment. After sorting, an aliquot of both positive and negative cell populations was taken and analysed by flow cytometry. The $\mathrm{x}$ axis represents the fluorescence of FITC-conjugated anti-CD3 $\mathrm{mAb}$ and the $\mathrm{y}$ axis represents relative cell number of unseparated cells ( $85 \%$ of $\mathrm{CD}^{+}$cells) (A), the $\mathrm{CD}^{+}$cell fraction ( $99 \%$ purity) (B1), the $\mathrm{CD}^{-}$cell fraction ( $94 \%$ purity) (B2) after MACS sort and CD3 ${ }^{*}$ cell after MACS + FACS sort ( $99 \%$ purity) (C).

Unsorted cells

A 8

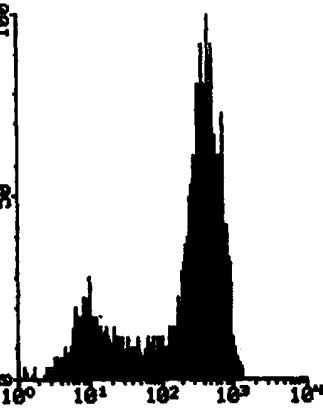

MACS sorting

B1

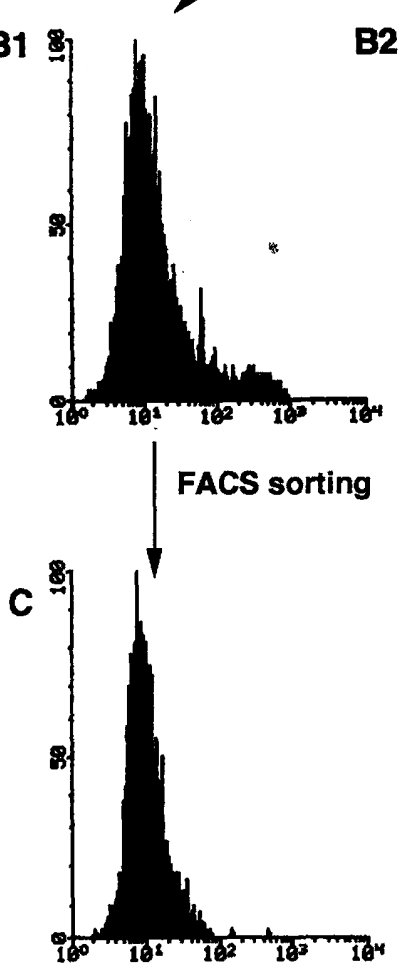

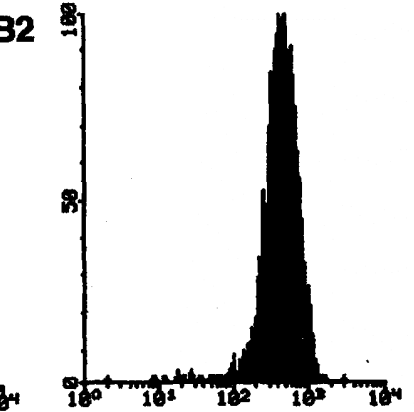


Table III: Cell surface phenotype of unseparated and purified cell fractions after in vitro activation.

$\mathrm{CD}$ designation $\quad$ Unsorted cells $\%$ of cells $\pm \quad \mathrm{CD}^{-}$cell fraction $\%$ of cells $\quad \mathrm{CD}^{+}$cell fraction $\%$ of $\mathrm{SD}$ $\pm \mathrm{SD}$ cells \pm SD

\begin{tabular}{llll}
\hline CD3 & $84 \pm 5$ & $1.5 \pm 1$ & $97.5 \pm 1.5$ \\
TcR $\alpha \beta$ & $82.5 \pm 6.5$ & ND & ND \\
TcR $\gamma \delta$ & $3.5 \pm 2$ & ND & ND \\
CD2 & $88 \pm 7.5$ & $45 \pm 6.5$ & ND \\
CD4 & $64.5 \pm 9.5$ & $3.5 \pm 1$ & $67 \pm 4$ \\
CD8 & $30 \pm 9.5$ & $30.5 \pm 4.5$ & $31 \pm 4$ \\
CD16 & $3.5 \pm 2$ & $31 \pm 4$ & $<1$ \\
CD56 & $6 \pm 2$ & $49 \pm 9$ & $2 \pm 1$ \\
CD57 & $5.5 \pm 1$ & $27 \pm 8$ & ND \\
CD25 & $67 \pm 16.5$ & $38 \pm 5$ & $71 \pm 1.5$ \\
CD19 & ND & $27 \pm 5.5$ & ND \\
CD20 & $8 \pm 4$ & ND & $\leq 1.5$ \\
CD45 & $98.5 \pm 1$ & $98 \pm 1$ & ND \\
CD14 & $0.5 \pm 0.5$ & $0.5 \pm 0.5$ & ND \\
\hline
\end{tabular}

After 4 days of culture in the presence of anti-CD3 $\mathrm{mAb}+\mathrm{rIL2}$, cells were sorted with MACS alone for the $\mathrm{CD}^{+}$cell fraction and with MACS + FACS for the CD3 ${ }^{-}$cell fraction when purity did not attain $95 \%$. Double staining was performed on unseparated and $\mathrm{CD}^{-}$cell fractions. ND = not done.

Fig. 3: Cytotoxic activity by unsorted and purified $C D 3^{+}$and $C D 3^{-}$fractions. Specific lysis determined in a 4-h chromium release assay are shown for an effector : target cell ratio of 20:1 against K562 cell line (A), Daudi (B), U937 (C) and HL60 (D). Means \pm SD from 4 independent experiments are shown.
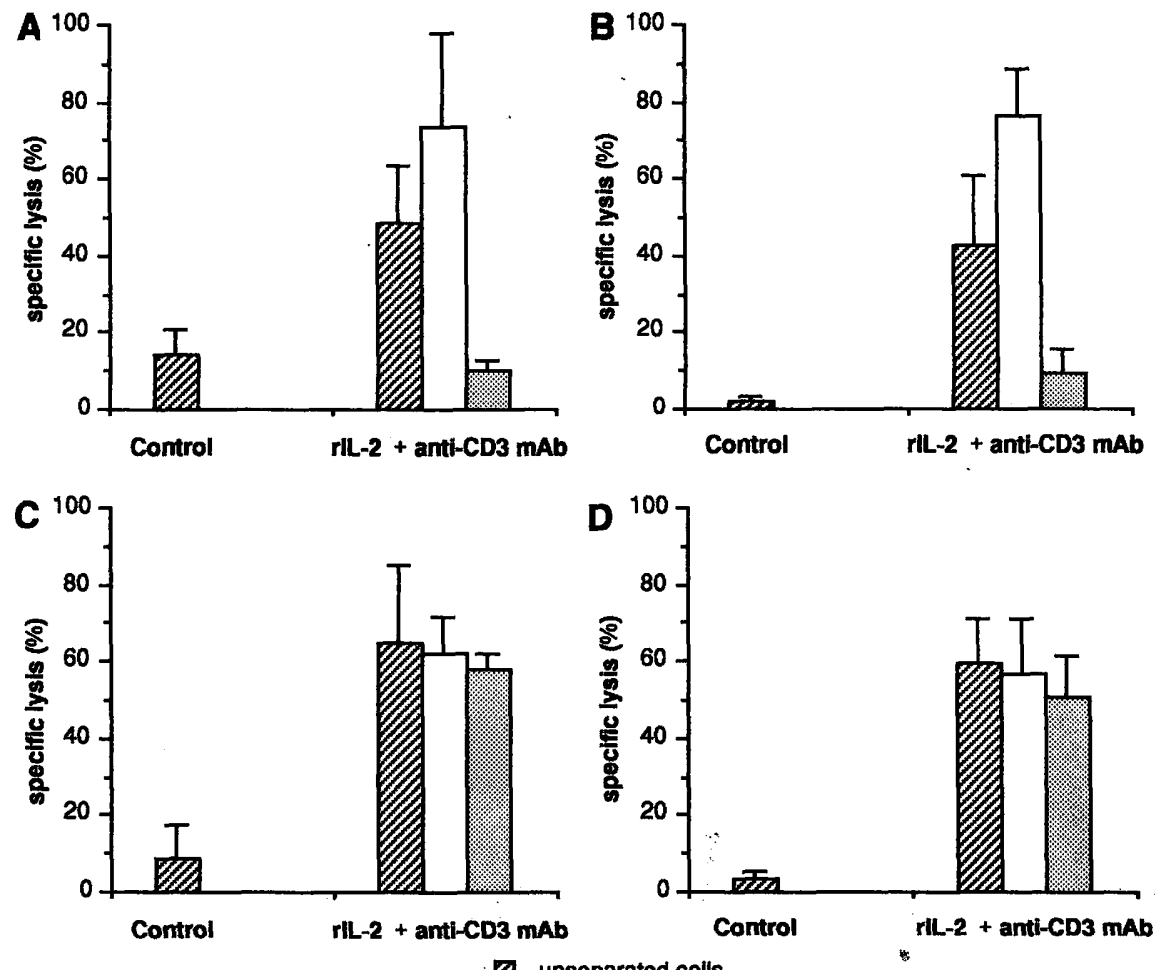

Z unseparated cells

$\square$ CD3-cell fraction

CD3+ cell fraction 


\section{MACS purification does not interfere with cytotoxic activity or anti-CD3-induced proliferation}

Cytolytic activity of unseparated and sorted cells was measured in a 4-h chromium release assay against K562, Daudi, U937 and HL60 target cell lines. The stimulation with the anti-CD3 mAb and rIL2 induced a highly significant $(\mathrm{p}<0.05)$ activity against all target cell lines (fig. 3$)$. Depletion of $\mathrm{CD}^{+} \mathrm{T}$ cells was associated with enrichment of the cytolytic activity against K562 and Daudi cell targets (fig. 3 A and B). Accordingly, CD3 ${ }^{+}$ cells did not show any significant lysis of these targets. On the other hand, depletion of T cells did not modify the activity detected against U937 and HL60 cell targets which were lysed similarly by effector cells from CD ${ }^{+}$ and $\mathrm{CD}^{-}$purification fractions (fig. 3C and 3D). This unmodified activity against U937 and HL60 target cells suggested that the weak cytolytic activity displayed by activated T cells against K562 and Daudi cell targets was not an artefact due to a functional inhibition by MACS selection.

As controls, we looked at the possible functional interferences of the MACS system due to non-specific factors independent of the antibody used for selection. The passage of unstimulated cells, prepared in the absence of antibodies, through the separation column did not modify the level of spontaneous DNA synthesis (fig. 4), indicating that the MACS isolation procedure does not in itself induce cell activation. Furthermore, the proliferative response of these cells to PHA was not increased by the MACS procedure (fig. 4).

The influence of MACS purification on proliferative responses were also studied at the effector stage. When PBL were activated for 4 days with anti-CD3 + rIL2, the isolation procedure purification with MACS did not modify DNA synthesis in the 24-h period after the sort (fig. 5). Finally, the specific influence of the isolation process on cytolytic activity at the effector stage was studied on IL2-activated lymphocytes. Neither the passage through the column nor the presence of the beads throughout the cytolytic assay modified the lysis of K562 by IL2-activated lymphocytes (data not shown).

\section{DISCUSSION}

In the present report, the MACS system proved to be an efficient technique for obtaining highly purified $\mathrm{CD}^{+} \mathrm{T}$ lymphocytes by positive selection from a heterogeneous population of PBL activated in vitro with anti-CD3 $\mathrm{mAb}+\mathrm{rIL} 2$. Negative selection of $\mathrm{CD}^{-}$cells from the same population did not lead to similar purity, although values higher than $95 \%$ were observed in some experiments. This difference between the efficiency of positive versus negative selection is likely to be due to the model itself rather than to intrinsic characteristics of the MACS system. Since CD3- lymphocytes only represented a minor cell subset in our model of activation, their negative purification by one cycle of MACS may have been hampered by the large proportion of CD3 ${ }^{+} \mathrm{T}$ cells. Furthermore, we observed that after culture in the presence of anti-CD3 mAb, the density of membrane expression of CD3 by T cells was heterogeneous, suggesting different kinetics of modulation or reexpression of the TcR-CD3 complex. Therefore, T cells expressing a low density of CD3 complexes could have bound a number of beads insufficient to be retained in the positive fraction. These cells could have consequently contaminated the negative fraction. Interestingly, when fresh or rIL2-activated PBL were studied, the expression of CD3 was found to be homogeneous, and negative selection of CD3-cells was constantly more efficient than after culture with anti-CD3 mAb + rIL2 (unpublished results). Accordingly, Abts et al. (1989), working on MACS purification of fresh human PBL, reported purities higher than $98 \%$ after negative selection of CD3lymphocytes. Similar results were observed by Schmitz and Radbruch (1989) using MACS negative selection of Thy-1 lymphocytes in a murine model. Since most contaminating $\mathrm{CD}^{+}$cells in our experiments expressed a low density of this marker, another sorting system based on the quantitative expression of the molecule (FACS) was chosen to improve the purity rather than several sequential runs of MACS sorting.

The heterogeneous density of CD3 expression after anti-CD3 mAb activation suggested that some T lymphocytes could present a CD3- ${ }^{-}$phenotype. In order to rule out contamination of the CD3- fraction by $\mathrm{T}$ lymphocytes with no membrane expression of the TcR-CD3 complex, intracytoplasmic labelling of CD3 was performed and did not reveal significant numbers of cells with cytoplasmic positivity for CD3 (unpublished results). 
Fig. 4: Effect of MACS beads and column on cell proliferation. PBL were cultivated in medium alone (control) or in the presence of PHA (1\%) for 3 days. At the beginning of culture, cells were either incubated with beads or passed through the column, or else underwent both procedures. Values shown represent the means plus SD of the triplicate; the log scale was used to enable visualization of control and PHA conditions.

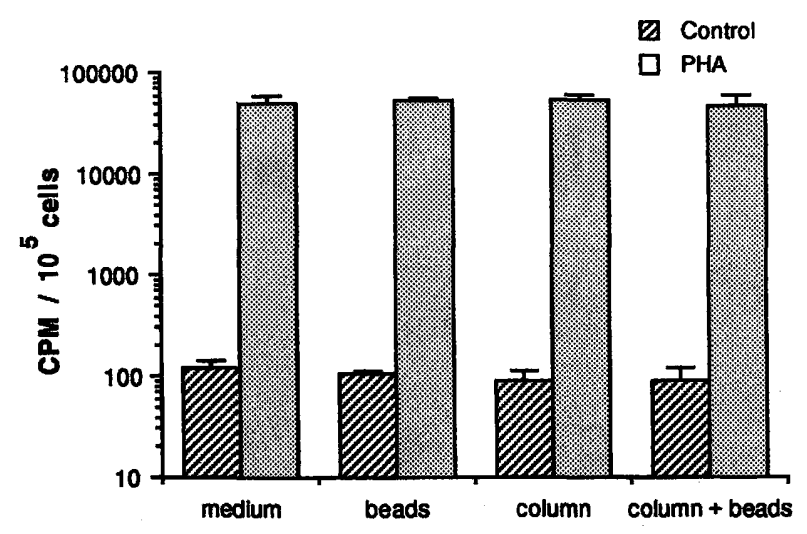

Fig. 5: Proliferative response to rIL2. Unstimulated (control), unseparated $\mathrm{CD}^{-}{ }^{-}$and $\mathrm{CD}^{+}$cells were cultivated in complete medium in the presence of $50 \mathrm{U} / \mathrm{ml}$ of rIL2 for $24 \mathrm{~h}$. Values shown represent the means plus SD of the triplicate.

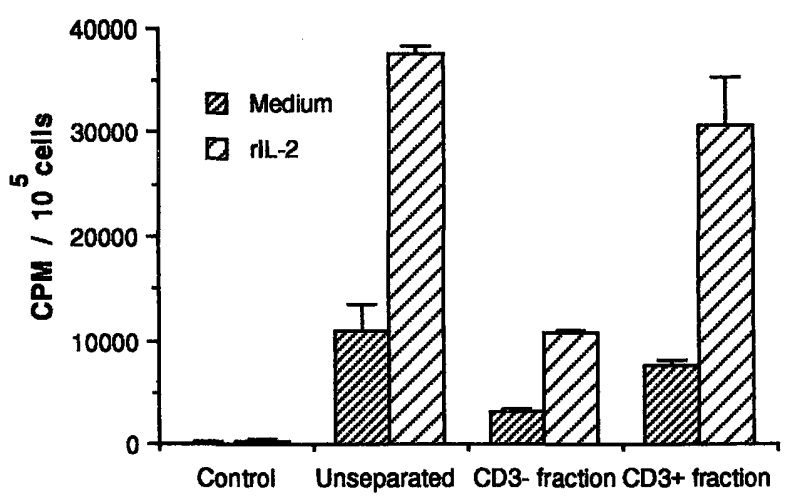

MACS purification of $\mathrm{CD}^{+}$cells led to over $95 \%$ purity in all experiments. However, the level of purity was further improved by a combination of MACS + FACS sorting, with purities higher than $99 \%$. In order to estimate whether this difference in purity could have any practical importance in our model, we compared the cytolytic activity displayed by T cells positively selected according to each protocol (MACS versus MACS + FACS). No significant difference could be found against any of the targets considered (unpublished results). This confirmed that the strong cytolysis of U937 and HL60 lines was actually due to T cells.

Given the absence of clearly defined markers for all non-T cells with non-MHC-restricted cytotoxicity, negative selection of these cells by elimination of $\mathrm{T}$ lymphocytes remains the most straightforward approach to determining the respective participation of these subsets in the LAK phenomenon. Despite the limitations of negative selection of $\mathrm{CD}^{-}$cells by MACS, combined MACS + FACS purification was always highly efficient and presented major advantages compared to purification with FACS alone. An important property of immunomagnetic selection compared to FACS is that the duration of the sorting procedure does not depend on the total number of cells to select. In our hands, positive selection of $\mathrm{CD}^{+} \mathrm{T}$ cells from a heterogeneous population of $200 \times 10^{6}$ cells did not demand more time than purification from $20 \times 10^{6}$ cells, while equivalent purity was obtained in both cases (unpublished results).

In addition, MACS presents several advantages over other, previously described magnetic selection systems. The latter were designed to be used with a higher beads/cell ratio for negative selection than for positive selection. Consequently, both selections had to be realized separately and the reciprocal selection fraction is systematically lost. On the other hand, MACS enables the simultaneous performing of positive and negative selection from the 
same heterogeneous population, since the same beads/cell ratio is used in both cases.

In the experiments described above, we directly used positively and negatively selected cells in proliferation and cytolytic assays without performing the procedures usually prescribed to detach the beads from the cells in other immunoselection systems, i.e. 24-hour incubation (Lea et al., 1986) or addition of goat anti-mouse-Fab antiserum (DetachaBead Dynal, Rasmussen et al., 1992). No significant interference of MACS selection with cell function was observed. The magnetic beads and the passage through the separation column did not induce any stimulatory or inhibitory effect on the proliferative and cytolytic responses of resting as well as stimulated lymphocytes. The anti-CD3 mAb used for selection may have stimulatory effects, especially when sorting is performed at the precursor stage. However, at the effector stage, it is unlikely that any triggering effect could modify the cytolytic activity of lymphocytes already cultivated for several days in the presence of anti-CD3 $\mathrm{mAb}$. We showed that the proliferation of lymphocytes previously incubated with anti-CD3 mAb was unchanged after positive selection of $\mathrm{T}$ cells with anti-CD3. Furthermore, the cytolytic activity of unsorted cells was unmodified by incubation with beads and anti-CD3 mAb whatever the way the cells had been stimulated (i.e. IL2 or IL2 + anti-CD3 mAb) (unpublished data).

To formally rule out any influence of MACS sorting on cytotoxicity, the functional study of the same subsets sorted by the reciprocal fashion (i.e. $\mathrm{CD}^{-}$cells positively sorted and $\mathrm{CD}^{+} \mathrm{T}$ cells negatively sorted) should be performed. However, due to the absence of a universal marker for all activated non-T cells with cytotoxic activity, this approach is more complex and several antibodies have to be used during the same sorting. Experiments are in progress to characterize $\mathrm{CD}^{-}$and $\mathrm{CD}^{+}$subsets obtained by such sorting approaches.

In accordance with a previous report (Ochoa et al., 1989), we found that the CD3- fraction was dramatically enriched in cytolytic effectors against K562 and Daudi. On the other hand, cytolytic activity against U937 and HL60 was similar in unsorted, $\mathrm{CD}^{-}$and $\mathrm{CD}^{+}$cells. Assays are currently in progress to determine whether lysis of $\mathrm{U} 937$ and HL60 by CD3 ${ }^{+}$cells is dependent on the binding of the anti-CD3 mAb by Fc receptors present on the target cells (mAb-redirected cytotoxicity). However, whatever the mechanism responsible, this finding proved that MACS purification did not inhibit the cytolytic machinery of the cells. Taken together, our results showed that immunomagnetic selection with MACS is a practical approach for the purification of cytolytic lymphocyte subsets at the effector stage.

\section{Acknowledgements}

This work was supported in part by the Fund for Medical Scientific Research (Belgium), Télévie, the Research Fund of the Faculty of Medicine of Liège, and the Centre anticancéreux près l'Université de Liège. N. Jacobs was supported by the Euvre Belge du Cancer and M.P. Moutschen by the National Fund for Scientific Research and Télévie.

The authors wish to acknowledge the excellent technical assistance of E. Franzen-Detrooz and are grateful to Glaxo for the gift of rIL2 and Becton Dickinson for financial support.

\section{References}

Abts, H., Emmerich, M., Miltenyi, S., Radbruch, A. \& Tesch, H. (1989), CD20-positive human B lymphocytes separated with magnetic cell sorter (MACS) can be induced to proliferation and antibody secretion in vitro. J. Immunol. Methods, 125, 19-28.

Collins, S.J., Gallo, R.C. \& Gallagher, R.E. (1977), Continuous growth and differentiation of human myeloid leukaemic cells in suspension culture. Nature (Lond.), 270, 347-349.

Gee, A.P., Mansour, V.H. \& Weiler, M.B. (1991), Effects of target antigen density on the efficacy of immuno-magnetic cell separation. $J$. Immunol. Methods, 142, 127-136.

Horan, P.K. \& Kappler, J A. (1977), Automated fluorescent analysis for cytotoxicity assays. J. Immunol. Methods, 18, $309-316$.

Klein, E., Klein, G., Nadkarni, J.S., Nadkarni, J.J., Wigzell, H. \& Clifford, P. (1968), Surface IgM-kap-pa specificity on a Burkitt lymphoma cell in vivo and in derived culture lines. Cancer Res., 28, 1300-1310.

Lea, T., Vartdal, F., Davies, C. \& Ugelstad, J. (1985), Magnetic monosized polymer particles for fast and specific fractionation of human mononuclear cells. Scand. J. Immunol., 22, 207-216. 
Lea, T., Smeland, E., Funderud, S., Vartdal, F., Davies, C, Beiske, K. \& Ugelstad, J. (1986), Characterization of human mononuclear cells after positive selection with immunomagnetic particles. Scand. J. Immunol., 23, 509-519.

Lindmo, T., Peters, D.C. \& Sweet, R.G. (1990), Flow sorter for biological cells, in "Flow cytometry and sorting" (second ed.) (M.R. Melamed, T. Lindmo \& M.L. Mendelsohn) (pp. 145-169). Wiley-Liss, Inc., New-York.

Lozzio, C.B. \& Lozzio, B.B. (1975), Human chronic myelogenous leukaemia cell line with positive Philadelphia chromosome. Blood, 45, $321-326$.

Miltenyi, S., Müller, W., Weichel, W. \& Radbruch, A. (1990), High gradient magnetic cell separation with MACS. Cytometry, 11, $231-238$.

Naume, B., Nonstad, U., Steinkjer, B., Funderud, S., Smeland, E. \& Espevik, T. (1991), Immunosélection of NK and LAK cells. J. Immunol. Methods, 136, 1-9.

Nishimura, T., Nakamura, Y., Takeuchi, Y., Tokuda, Y., Iwasawa, M., Kawasaki, A., Okumura, K. \& Habu, S. (1992), Generation, propagation, and targeting human $\mathrm{CD}^{+}$helper/killer T cells induced by anti-CD3 monoclonal antibody plus recombinant IL-2. An efficient strategy for adoptive tumor immunotherapy. J. Immunol., 148, 285-291.

Ochoa, A.C., Gromo, G., Alter, B.J., Sondel, P.M. \& Bach, F.H. (1987), Long-term growth of lymphokine-activated killer (LAK) cells: role of anti-CD3, $\beta$-IL-1, interferon- $\gamma$ and - $\beta$. J. Immunol., 138, 2728-2733.

Ochoa, A.C., Hasz, D.E., Rezonzew, R., Anderson, P.M. \& Bach, F.H. (1989), Lymphokine-activated killer activity in long-term cultures with anti-CD3 plus interleukin-2: identification and isolation of effector subsets. Cancer Res., 49, 963-969.

Pflueger, E., Mueller, E.A. \& Anderer, F.A. (1990), Preservation of cytotoxic function during multi-cycle immunomagnetic cell separations of human NK cells using a new type of magnetic bead. J. Immunol. Methods, 129, 165-173.

Rasmussen, A.-M., Smeland, E.B., Erikstein, B.K., Caignault, L. \& Funderud, S. (1992), A new method for detachment of Dynadeads from positively selected B lymphocytes. J. Immunol. Methods, 146, 195-202.

Schmitz, J. \& Radbruch, A. (1989), An interleukin-4-induced DNase I hypersensitive site indicates opening of the $\gamma 1$ switch region prior to switch recombination. Int. Immunol., 1, 570-575.

Sundström, C. \& Nilsson, K. (1976), Establishment and characterization of a human histiocytic lymphoma cell line (U-937). Int. J. Cancer, 17, 565-577. 